state. It is of particular interest for its bird life, notably as the sole British breeding ground of the Kentish plover. Other uncommon birds also nest there, such as the stone eurlew, and there is a large colony of terns. All this may soon be irretrievably lost if a threat of bungalow building along the sea-front cannot be averted. To secure the position, therefore, efforts are being made to raise $£ 9000$ for the purchase of 271 acres as a bird sanctuary and Nature reserve, to be administered either by the National Trust or by the Royal Society for the Protection of Birds. This area, with its half-mile of shore frontage, is the part immediately in danger, and its price is, unfortunately, already that of a building site. Its acquisition, however, would increase the sanctuary value of adjacent land that is already preserved, and would make inaccessible to development a further stretch of coast lying beyond. The area is thus a key position, and the success of the scheme for its security is very greatly to be desired. The treasurer of the fund is Mr. Percival Jackling, Lloyds Bank, Folkestone.

\section{The Grid and the Cost of Electricity}

Is connexion with Sir Archibald Page's speech, a résumé of which was given in NATURE of Aug. 6, p. 212, Col. H. L. Crosthwait, late R.E., writes asking whether the advent of the 'grid' is likely to reduce the price of electricity or not. So far as can be seen at present, it will reduce the price to numerous consumers. The large stations recently built are generating electricity with far greater economy than the older stations which they replace. The use of the grid will be a great help in securing continuity of supply, and will make it unnecessary to keep a large number of costly machines in reserve in case of breakdowns. The standardisation of the pressures and frequency of supply has cheapened the cost of machines, apparatus, and lamps. We have not heard complaints from any consumer that the electricity companies have been raising the price of electricity; on the contrary, many of them have recently made substantial reductions. It is probable that some consumers will be little affected by the advent of the grid, but many will get their electricity cheaper, and very many dwellers in towns and villages will be able to get electric light and power which they otherwise would not have obtained. The grid is the logical engineering outcome of Ferranti's scheme for lighting London, using electricity at high pressures, first put into operation about forty-four years ago. Its critics have suggested nothing better; as a rule, they desire progress to be made by costly competitive methods. In the future the grid will probably be considerably modified, but at present consumers can look forward to a gradual lowering of the price of electric light and power.

\section{Monument to Otto Lilienthal}

ON Aug. 10 a monument to Otto Lilienthal, the German pioneer of gliding flight, was inaugurated at East Lichterfelde, Berlin, on the mound from which Lilienthal made many of his flights forty years ago. The mound, which was piled up for the purpose by
Lilienthal, is some forty-nine feet high, and a photograph taken some years ago shows its sides covered by shrubs and the top surmounted by a small temple-like construction consisting of pillars supporting a slightly sloping round roof. According to the Times for Aug. 10, the mound has now been cleared of the trees and shrubs, while in the monument at the top, and beneath the central opening in the roof, is a silver globe inscribed with particulars of famous flights. The globe is mounted on a basalt block. A photograph of the inauguration of the memorial appeared in the Times for Aug. 11. Lilienthal was a successful engineer and manufacturer. He was born on May 23, 1848, at Anklam and died on Aug. 10, 1896, at Rhinow through an accident while gliding. Another monument to Lilienthal was inaugurated at Lichterfelde in 1914. This consists of a stone pyramid, bearing on one side a bust and on the summit a figure of a man with outstretched arms supporting a pair of wings.

\section{The Workers' Educational Association and Science}

AT the Annual Conference of the Workers' Educational Association last year, it was resolved "to investigate the possibilities of stimulating further interest in the study of science [that is, natural science] on a non-vocational basis", and the result of the investigation by the Executive Committee has now been circulated. To a scientific worker, it seems in some respects a strange document to be produced in 1932. It says, "The Adult Education Movement cannot afford to neglect scientific thought and knowledge. Ignorance of the influence of science should belong to the past" ; and then, "The study of science, in some of its branches, provided the approach is of the right character, is as attractive and has as great a bearing on social conditions as some of the social sciences". As if the very foundations of social conditions did not rest upon heredity, and health, and the fight against disease, and the production of food, whether from the fisheries or agriculture, and the growing of the raw materials of commerce, and the constant battle against pests, whether they be parasites or plagues, and upon life itself! The Report says, further, "It is only in relation to the question as to how far and in what ways natural science influences and affects society, that our classes can maintain their interest in subjects of this character". It is on strong ground, however, in holding that the teaching of natural science, in so far as it is to be promoted, should avoid the formal lines of a university degree course, and should be of such a character as to attract the uninitiated.

Tre Committee, basing upon its district reports, finds that "there is a lack of interest so far as the adult population is concerned in the study of science ". We think this may be due partly to the ignorance of people as to what natural science means, and partly to the failure to offer suitable courses. But we congratulate the Committee on its unanimous opinion " that the Association should seek to stimulate further interest amongst adult students in the study of science on a non-vocational basis". Towards this end it makes several recommendations, of which the most 